\title{
Verzeichnis der Kartenbeilagen
}

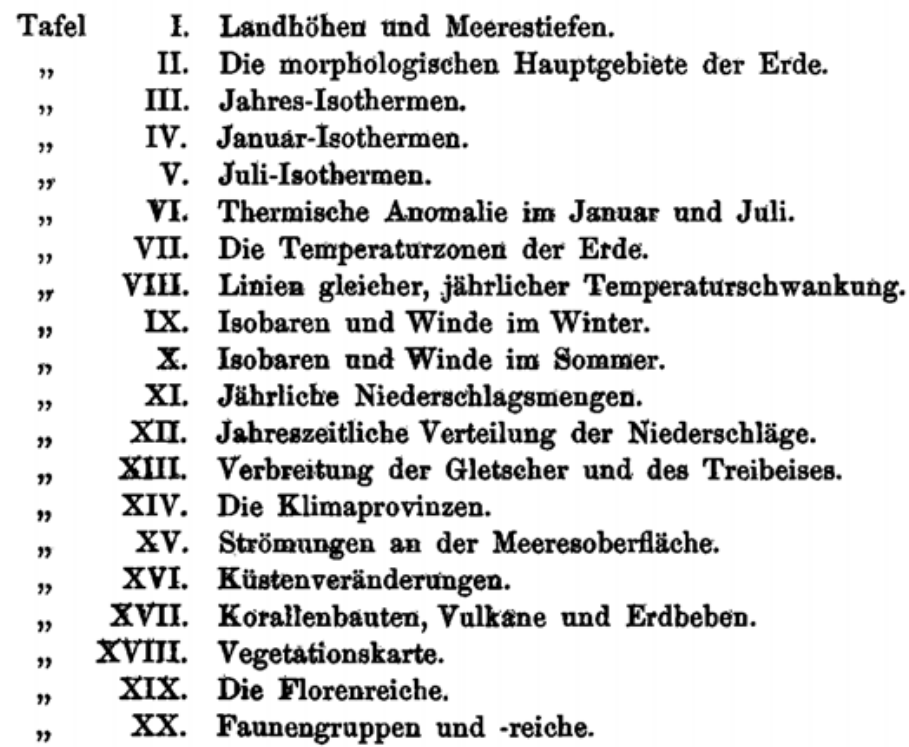

